\title{
Pengaruh Gambut Terbakar Terhadap Beberapa Sifat Fisika Gambut di Kecamatan Tripa Makmur
}

\author{
(The Effect of Burning Peat on Some of the Physical Porperties of Peat Soil in The Tripa \\ Makmur Sub District)
}

\author{
Teuku Muhammad Afrizal ${ }^{1}$, Hairul Basri ${ }^{1}$, M. Rusli Alibasyah ${ }^{1^{*}}$ \\ ${ }^{1}$ Program Studi Ilmu Tanah, Fakultas Pertanian, Universitas Syiah Kuala
}

\begin{abstract}
Abstrak. Gambut mengandung bahan organik yang tinggi. Gambut yang didrainase rentan terhadap kebakaran. Pemanfaatan gambut di Aceh sangat luas. Umumnya, gambut sering dibakar agar dapat dengan cepat dimanfaatkan., khususnya di Kecamatan Tripa Makmur Kabupaten Nagan Raya. Penelitian ini bertujuan untuk melihat seberapa jauh tingkat perubahan sifat fisika gambut terbakar Rawa Tripa Kabupaten Nagan Raya. Hasil penelitian menunjukkan bahwa rata-rata berat volume tertinggi terdapat pada sampel $\mathrm{T}_{1}$ (top soil) yaitu $0,36 \mathrm{~g}$ $\mathrm{cm}^{-3}$ dan terendah pada $\mathrm{T}_{0}$ (sub soil) yaitu $0,17 \mathrm{~g} \mathrm{~cm}^{-3}$. Kadar air tertinggi terdapat pada sampel $\mathrm{T}_{0}$ (sub soil) yaitu $234,82 \%$ dan terendah pada $\mathrm{T}_{1}$ (top soil) yaitu $81,96 \%$. Porositas tertinggi terdapat pada sampel gambut $\mathrm{T}_{0}$ (sub soil) yaitu $94,93 \%$ dan terendah pada $\mathrm{T}_{1}$ (top soil) yaitu $65,28 \%$. Permeabilitas tertinggi terdapat pada $\mathrm{T}_{0}$ ( sub soil) yaitu 33,80 cm/jam dan terendah pada $\mathrm{T}_{1}$ (top soil) yaitu $16,10 \mathrm{~cm} / \mathrm{jam}$. Hasil uji statistik menunjukkan bahwa ada perbedaan yang signifikan pada parameter berat volume dengan $t$ hitung $(3,482)>t$ tabel $(1,943)$, sedangkan pada parameter lainnya tidak ada perbedaan yang signifikan. Tingkat kematangan gambut di kawasan Tripa Makmur adalah hemik. Kedalaman gambut sebesar 3 meter. Subsiden tertinggi adalah $100 \mathrm{~cm}$ pada gambut terbakar di tahun 2015. Warna gambut adalah coklat kehitaman
\end{abstract}

Kata Kunci: Gambut Terbakar, Sifat Fisika, Nagan Raya.

Abstract. Peat contains high organic matter. Drained peat is susceptible to fire. The use of peat in Aceh is very broad. Peat is often burned so that it can be quickly utilized especially in Tripa makmur Sub Districk, Nagan Raya Districk. This study aims to see how far the rate of change in the physical properties of peat is burning Rawa Tripa in Nagan Raya District. The results showed that the highest average of volume weight was found in $\mathrm{T}_{1}$ (top soil) $0,36 \mathrm{~g} \mathrm{~cm}^{-3}$ and the lowest in $\mathrm{T}_{0}$ (sub soil) $0,17 \mathrm{~g} \mathrm{~cm}^{-3}$. The highest water content was found in $\mathrm{T}_{0}$ (sub soil) $234,82 \%$ and the lowest was on $\mathrm{T}_{1}$ (top soil) $81,96 \%$. The highest porosity was found $\mathrm{T}_{0}$ (sub soil) $94,93 \%$ and the lowest in $\mathrm{T}_{1}$ (top soil) $65,28 \%$. The highest permeability is found in $\mathrm{T}_{0}$ (sub soil) $33,80 \mathrm{~cm} / \mathrm{hour}$ and the lowest is on $\mathrm{T}_{1}$ (top soil) $16,10 \mathrm{~cm} /$ hour. The results of statistical tests show that there is a significant difference in the parameters of volume weight with $\mathrm{t}$ count 3,482 > t table 1,943, while in the other parameters have no significant differences. The level of maturity in the Tripa Makmur area is hemik. Peat depth of 3 meters. The highest subsidance is $100 \mathrm{~cm}$ on burning peat in 2015. The color of this peat is blackish brown.

Keywords: Burning Peat, Physical Properties, Nagan Raya.

\section{PENDAHULUAN}

Lahan gambut adalah lahan yang memiliki lapisan tanah yang kaya dengan bahan organik. Bahan penyusun tanah gambut terbentuk dari sisa-sisa tanaman yang belum melapuk sempurna karena kondisi lingkungan jenuh air (organik). Penyebaran lahan gambut di Indonesia, diperkirakan 20,6 juta hektar $(10,8 \%)$ dari luas daratan Indonesia. 7,2 juta hektar 
(35\%) berada di pulau Sumatera dan 5,67 juta hektar (27,8\%) terdapat di Kalimantan (Wahyunto et al., 2004).

Pemanfaatan lahan gambut sungguh sangatlah besar, hal ini dikarenakan lahan konvensional yang semakin menipis sehingga lahan gambut menjadi target perluasan lahan pertanian/perkebunan. Dalam pemanfaatan lahan gambut itu sendiri harus melewati berbagai macam tahapan diantaranya pembuatan drainase, akan tetapi diantara tahapan dalam pengelolaan gambut ada tahapan yang kurang baik, yaitu dengan dilakukannya pembakaran gambut, guna untuk mempercepat proses pengelolaan gambut itu sendiri. Pembakaran lahan gambut dilakukan pada saat persiapan sebelum musim tanam atau musim kemarau. Hal ini sering terjadi karena kesengajaan dari petani dengan tujuan untuk mendapatkan abu sebagai mineral untuk memadatkan gambut serta memperbaiki $\mathrm{pH}$ dan kejenuhan basa (Subiksa et al., 2009).

Lahan gambut akan mudah terbakar apabila setelah di drainase, dilihat dari bahan utamanya juga yaitu serasah tanaman yang melapuk dengan ketebalan $>50 \mathrm{~cm}$, sehingga membuatnya susah untuk memadamkannya (Agus dan Subiksa, 2008). Tujuh hari setelah terbakar pada setiap kedalaman $(10-20 \mathrm{~cm})$ gambut mengalami penurunan kemampuan untuk mengikat air (water holding capacity) dibandingkan dengan gambut tidak terbakar (Tahrun, 2015). Penurunan lapisan gambut juga terjadi akibat ruang pori yang biasanya diisi oleh air menjadi hilang, sehingga volume gambut mengecil dan kemampuan menyerap air pun berkurang (Sabiham, 2007). Akibat dari pembakaran gambut mengganggu kualitas alami gambut yang meliputi sifat fisik gambut yang menjadi kajian.

Kabupaten Nagan Raya, Kecamatan Tripa Makmur, Desa Rawa Tripa, sudah cukup banyak terjadi pembakaran lahan gambut, pada kawasan tersebut sekarang dimanfaatkan untuk lahan perkebunan kelapa sawit dan telah terbakar sejak tahun 2012 (Prijono, 2016). Kebakaran lahan gambut mengakibatkan terjadinya perubahan baik terhadap sifat fisik gambut maupun sifat lainnya dan membuat sifat alami gambut berubah, sehingga mengganggu ekosistem di daerah sekitar, oleh karena itu perlu dilakukan penelitian terhadap perubahan sifat fisika gambut terbakar di Kecamatan Tripa Makmur.

\section{METODE PENELITIAN}

Penelitian ini dilaksanakan di Laboratorium Fisika tanah dan Lingkungan Fakultas Pertanian Universitas Syiah Kuala dengan wilayah kajian Desa Babah Lueng Kecamatan Tripa Makmur Kabupaten Nagan Raya.

\section{MATERI DAN METODE}

Alat yang digunakan dalam penelitian antara yaitu ring sample, bor gambut, buku Munsell Soil Color Chart, meteran, parang, GPS, cangkul, timbangan, kamera, kantung plastik transparan, kertas label, serta alat-alat tulis untuk menganalisis sifat fisika tanah di Laboratorium. Sedangkan bahan yang digunakan dalam penelitian ini diantaranya contoh tanah utuh, tanah komposit dan peta kerja. 
Metode yang digunakan pada penelitan ini yaitu metode deskriptif dengan teknik survei, sedangkan analisis data menggunakan analisis Laboratorium dan SPSS. Tahapan penelitian mencakup penentuan titik pengambilan sampel, pengamatan lapangan, dan analisis di Laboratorium. Urutan pelaksanaan penelitian dapat dilihat pada Gambar 1.

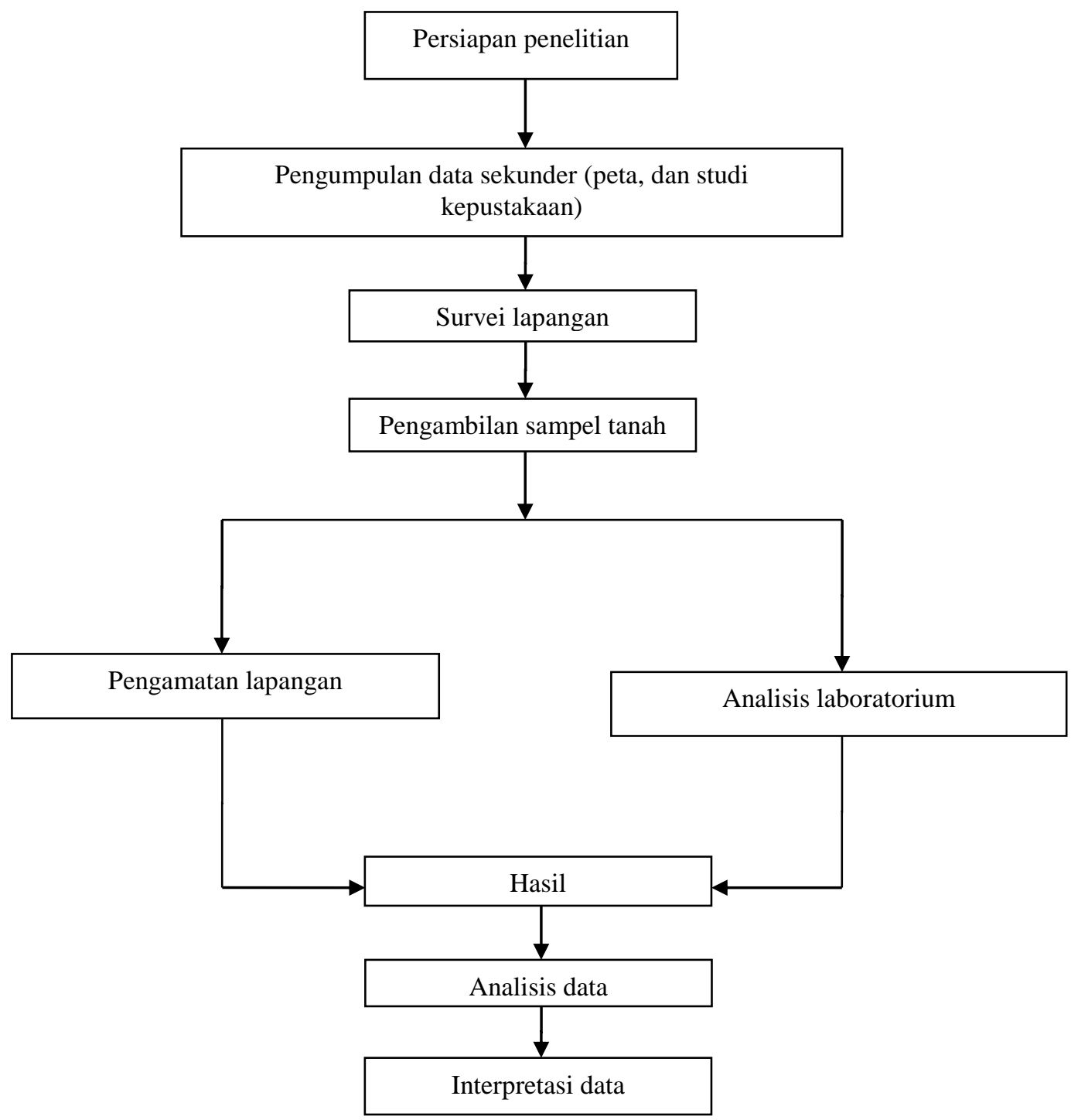

Gambar 1. Diagram alir penelitian 


\section{Pelaksanaan Penelitian}

\section{Penentuan Titik Pengambilan Sampel}

Titik sampel ditentukan berdasarkan peta kerja yang disesuaikan dengan keadaan lapangan. Sampel diambil di kawasan gambut tidak terbakar dan terbakar, yaitu pada tahun 2015, 2016, 2017. Jenis sampel tanah yang diambil adalah sampel tanah utuh dan tidak utuh. Pengambilan sampel tanah tidak utuh dilakukan dengan menggunakan bor gambut pada beberapa titik kemudian di kompositkan. Sedangkan pada sampel tanah utuh dengan menggunakan ring sample. Pengambilan sampel dilakukan dengan menggunakan metode proposive random sampling, pada gambut terbakar 2015 diambil dua titik berdasarkan luasannya dengan total 8 sampel, 4 sampel tanah utuh dan 4 sampel tanah tidak utuh di kedalaman 20 - $40 \mathrm{~cm}$ dan 40 - $80 \mathrm{~cm}$. Pada gambut terbakar 2016 dan 2017 diambil masingmasing tiga titik dengan total jumlah sampel berdasarkan tahun terbakarnya gambut adalah 12 sampel, sedangkan pada gambut yang tidak terbakar diambil 2 titik. Data pengambilan titik sampel dapat dilihat pada Tabel 1.

Tabel 1. Pengambilan titik sampel

\begin{tabular}{cccccc}
\hline No & $\begin{array}{c}\text { Umur Kelapa Sawit } \\
\text { (Tahun) }\end{array}$ & Luas (ha) & \multicolumn{2}{c}{ Kedalaman Sampel (cm) } & \multirow{2}{*}{$\begin{array}{c}\text { Jumlah } \\
\end{array}$} \\
\cline { 4 - 5 } & & & $20-40$ & $40-80$ & \\
\hline 1. & T0 & 1,00 & 4 & 4 & 8 \\
2. & T1 & 1,78 & 4 & 4 & 8 \\
3. & T2 & 12,22 & 6 & 6 & 12 \\
4. & T3 & 19,22 & 6 & 6 & 12 \\
\hline & Total & 34,22 & 20 & 20 & 40 \\
\hline
\end{tabular}

Keterangan:

$\mathrm{T}_{0}=$ Gambut yang tidak terbakar

$\mathrm{T}_{1}=$ Gambut terbakar pada tahun 2015

$\mathrm{T}_{2}=$ Gambut terbakar pada tahun 2016

$\mathrm{T}_{3}=$ Gambut terbakar pada tahun 2017

\section{Pengamatan Lapangan}

Pengamatan lapangan dilakukan pada lahan-lahan yang sudah ditanami kelapa sawit milik rakyat, kemudian diidentifikasikan faktor-faktor morfologi yang menentukan kualitas lahan untuk tanaman kelapa sawit yang ditanam di lahan gambut. Adapun parameter morfologi yang akan dilakukan dalam observasi di lapangan dapat dilihat pada Tabel 2.

Tabel 2. Sifat-sifat morfologi lahan gambut

\begin{tabular}{lll}
\hline No & Sifat Morfologi Yang Diamati & Alat atau metode pengamatan \\
\hline 1. & Tingkat kematangan (gambut tidak terbakar) & Diremas/diperas dengan tangan \\
2. & Kedalaman gambut (gambut tidak terbakar & Bor gambut/bor kedalaman efektif \\
& dan terbakar & Dilihat melalui berat volume \\
3. & Subsiden (gambut terbakar) & Soil Munsell Color chart \\
4. & Warna Tanah & \\
\hline
\end{tabular}

Perubahan Beberapa Sifat Fisika Dan Kimia Gambut Akibat Lamanya Penggunaan Lahan di Rawa Tripa Kabupaten Nagan Raya

(Teuku Muhammad Afrizal, Hairul Basri, M. Rusli Alibasyah)

Jurnal Ilmiah Mahasiswa Pertanian Unsyiah, Vol. 4, No. 1, Januari 2019: 472-481 


\section{Analisis di Laboratorium}

Pengamatan di laboratorium dilakukan setelah pengambilan sampel tanah di lapangan. Adapun analisis yang dilakukan di laboratorium adalah analisis fisika tanah dan lingkungan. Parameter yang dianalisis dapat dilihat pada Tabel 3.

Tabel 3. Komponen, parameter dan metode analisis laboratorium

\begin{tabular}{clll}
\hline No. & \multicolumn{1}{c}{ Parameter } & \multicolumn{1}{c}{ Satuan } & \multicolumn{1}{c}{ Metode Analisis } \\
\hline 1. & Permebilitas & $\mathrm{cm} / \mathrm{jam}$ & Volumetrik \\
2. & Berat volume tanah & $\mathrm{g} \mathrm{cm}^{-3}$ & Ring Sampel (Core) \\
3. & Porositas total & $\%$ & Gravimetri \\
4. & Kadar Air & $\%$ volume & Kering oven $\left(105^{\circ} \mathrm{C}\right)$ \\
\hline
\end{tabular}

\section{HASIL DAN PEMBAHASAN}

Sifat fisika gambut yang diambil di lokasi penelitian dan di analisis di Laboratorium Fisika Tanah dan Lingkungan yaitu peremeabilitas, berat volume, kadar air dan porositas, dapat dilihat pada Tabel 4 .

Tabel 4. Hasil analisis fisika tanah gambut Rawa Tripa

\begin{tabular}{|c|c|c|c|c|c|c|c|c|c|c|}
\hline \multirow{3}{*}{ No } & \multirow{3}{*}{ Kode Sampel } & \multirow{3}{*}{$\begin{array}{c}\text { Jumlah Sampel } \\
\text { Berdasarkan Titik Sampel }\end{array}$} & \multicolumn{8}{|c|}{ Parameter/Criteria } \\
\hline & & & \multicolumn{2}{|c|}{ Permeabilitas (cm/jam) } & \multicolumn{2}{|c|}{ Bulk density $(\mathrm{g} / \mathrm{cm} 3)$} & \multicolumn{2}{|c|}{ Kadar Air (\%) } & \multicolumn{2}{|c|}{ Porositas (\%) } \\
\hline & & & Jumlah data & Rata - rata & Jumlah data & Rata - rata & Jumlah data & Rata - rata & Jumlah data & Rata - rata \\
\hline \multirow{2}{*}{1} & \multirow{2}{*}{ Terbakar 2015 (top soil) } & Top Titik 1 & 23,48 & \multirow{2}{*}{22,95} & 0,37 & \multirow{2}{*}{0,36} & 86,82 & \multirow{2}{*}{81,96} & 69,19 & \multirow{2}{*}{65,28} \\
\hline & & Top Titik 2 & 22,43 & & 0,36 & & 77,11 & & 61,37 & \\
\hline \multirow{3}{*}{2} & \multirow{3}{*}{ Tebakar 2015 (sub soil) } & Sub Titik 1 & 17,46 & \multirow{3}{*}{16,10} & 0,33 & \multirow{3}{*}{0,32} & 96,08 & \multirow{3}{*}{93,97} & 70,25 & \multirow{3}{*}{68,29} \\
\hline & & Sub Titik 2 & 14,74 & & 0,32 & & 91,51 & & 66,54 & \\
\hline & & Top Titik 1 & 24,09 & & 0,31 & & 102,99 & & 79,07 & \\
\hline \multirow[t]{3}{*}{3} & \multirow[t]{3}{*}{ Terbakar 2016 (top soil) } & Top Titik 2 & 23,52 & \multirow[t]{2}{*}{22,59} & 0,32 & \multirow[t]{2}{*}{0,30} & 113,08 & 106,82 & 80,26 & \multirow[t]{2}{*}{76,28} \\
\hline & & Top Titik 3 & 20,14 & & 0,29 & & 104,39 & & 69,53 & \\
\hline & & Sub Titik 1 & 15,35 & & 0,29 & \multirow{3}{*}{0,28} & 117,02 & & 86,29 & \\
\hline \multirow[t]{3}{*}{4} & \multirow[t]{3}{*}{ Terbakar 2016 (sub soil) } & Sub Titik 2 & 16,64 & \multirow[t]{2}{*}{17,12} & 0,29 & & 122,40 & 116,30 & 83,79 & \multirow[t]{2}{*}{80,89} \\
\hline & & Sub Titik 3 & 19,38 & & 0,26 & & 109,48 & & 72,58 & \\
\hline & & Top Titik 1 & 28,23 & & 0,27 & & 110,00 & & 88,69 & \\
\hline \multirow[t]{3}{*}{5} & \multirow[t]{3}{*}{ Terbakar 2017 (top soil) } & Top Titik 2 & 26,38 & 26,26 & 0,27 & 0,26 & 154,73 & 146,94 & 80,14 & 87,38 \\
\hline & & Top Titik 3 & 24,17 & & 0,25 & & 176,08 & & 93,30 & \\
\hline & & Sub Titik 1 & 21,27 & & 0,25 & & 145,00 & & 94,83 & \\
\hline 6 & Terbakar 2017(sub soil) & Sub Titik 2 & 22,13 & 22,20 & 0,25 & 0,24 & 197,20 & 174,34 & 81,32 & 90,50 \\
\hline & & Sub Titik 3 & 24,17 & & 0,23 & & 180,82 & & 95,35 & \\
\hline & & Top Titik 1 & 33,31 & & 0,18 & & 217,14 & & 95,30 & \\
\hline 7 & Hutan (top soil) & Top Titik 2 & 34,29 & 33,80 & 0,19 & 0,19 & 221.97 & 219,56 & 92,27 & 93,78 \\
\hline 8 & & Sub Titik 1 & 32,88 & 3268 & 0,16 & & 223,99 & & 95,98 & \\
\hline 8 & Hutan (sub soil) & Sub Titik 2 & 32,48 & 32,68 & 0,17 & 0,17 & 245,65 & 234,82 & 93,88 & 94,93 \\
\hline
\end{tabular}

Sumber: Hasil analisis Fisika Tanah (2018)

\section{Permeabilitas}

Berdasarkan hasil analisis permeabilitas, diketahui bahwa nilai permeabilitas bervariasi antara 23,48 - 32,48 $\mathrm{cm} / \mathrm{jam}$, sampel $\mathrm{T}_{0}$ (gambut tidak terbakar) pada sub soil memiliki kadar air yang lebih tinggi yaitu $32,48 \mathrm{~cm} /$ jam dibandingkan dengan sampel tanah $\mathrm{T}_{1}, \mathrm{~T}_{2}$ dan $\mathrm{T}_{3}$. Penurunan nilai permeabilitas pada lahan gambut terbakar disebabkan oleh beberapa faktor, diantaranya adalah porositas, distribusi ukuran pori, stabilitas agregat serta kandungan bahan organik, pada hasil kebakaran akan memperkecil pori gambut sehingga menjadi padat. Penurunan jumlah bahan organik secara sistem perekaran juga menyebabkan nilai permeabilitas menurun.

Perubahan Beberapa Sifat Fisika Dan Kimia Gambut Akibat Lamanya Penggunaan Lahan di Rawa Tripa Kabupaten Nagan Raya 


\section{Berat Volume}

Berdasarkan hasil analisis di Laboratorium, berat volume tanah gambut di lokasi penelitian berkisar antara $0,17-0,36 \mathrm{~g} \mathrm{~cm}^{-3}$. Berat volume gambut tertinggi terdapat pada sampel top soil $T_{1}$ yaitu lahan gambut yang terbakar tahun 2015. Sedangkan berat volume terendah di sub soil $\mathrm{T}_{0}$ yaitu gambut yang tidak terbakar. Penurunan nilai berat volume gambut disebabkan karena abu yang hasil dari pembakaran, abu yang dihasilkan dari pembakaran gambut merupakan mineral yang meningkatkan berat volume gambut.

\section{Porositas}

Hasil analisis pada parameter porositas berkorelasi dengan lamanya gambut terbakar, dimana semakin lama tahun gambut terbakar maka semakin menurun porositasnya yaitu 65,28 - 94,93\%. Suhu yang meningkat akibat kebakaran pada struktur permukaan gambut dapat mengurangi ruang pori serta berkorelasi dengan berat volume yang mana dapat meningkatkan nilai berat volume gambut.

\section{Kadar Air}

Hasil analisis pada parameter kadar air berkorelasi pula dengan lamanya gambut terbakar, dimana semakin lama tahun gambut terbakar maka semakin menurun juga nilai kadar air gambut yaitu 81,96 - 234,82\%. Penurunan kadar air disebabkan karena bahan mineral (abu) hasil pembakaran yang mengisi ruang pori yang kosong dan menyumbatnya sehingga mengganggu proses penyimpanan air gambut.

\section{Tingkat Subsiden}

Berdasarkan hasil pengamatan di lapangan, didapatkan bahwa tingkat subsiden gambut pada areal penelitian memiliki korelasi positif dengan lamanya gambut terbakar. Nilai subsiden pada lahan gambut yang terbakar 2015, 2016 dan 2017 bervariasi yaitu mulai dari 60 - $100 \mathrm{~cm}$. Data tingkat subsiden gambut dapat dilihat pada Tabel 5.

Tabel 5. Tingkat Subsiden

\begin{tabular}{llcc}
\hline No & Lama Gambut Terbakar & $\begin{array}{c}\text { Kedalaman Gambut } \\
(\mathrm{m})\end{array}$ & $\begin{array}{c}\text { Tingkat Subsiden } \\
(\mathrm{cm})\end{array}$ \\
\hline 1 & Gambut Terbakar 2015 & 2,0 & 100 \\
2 & Gambut Terbakar 2016 & 2,1 & 90 \\
3 & Gambut Terbakar 2017 & 2,4 & 60 \\
4 & Gambut Tidak Terbakar & 3,0 & 0 \\
\hline
\end{tabular}

\section{Data Umum Lokasi Penelitian}

Berdasarkan hasil pengamatan di lapangan, didapatkan bahwa kedalaman gambut berada pada kriteria sangat dangkal yaitu sebesar 3 meter. Kedalaman gambut di lapangan sangat berkaitan dengan tingkat kematangan gambut dan drainase yang ada, semakin matang gambut maka semakin dangkal pula permukaan gambut. tingkat kematangan gambut dilokasi penelitian adalah hemik yaitu berkisar 25 - 30\% dengan kedalaman drainase dan lebar drainase adalah sebesar 3 meter dan 2,5 meter, hal ini juga mempengaruhi tingkat subsiden di lokasi penelitian, apabila laju drainase cepat maka terjadi subsidence (penurunan permukan)

Perubahan Beberapa Sifat Fisika Dan Kimia Gambut Akibat Lamanya Penggunaan Lahan di Rawa Tripa Kabupaten Nagan Raya 
yang mempengaruhi tingkat kedalaman gambut. Data umum hasil pengamatan di lokasi penelitian dapat dilihat pada Tabel 6 .

Tabel 6. Data Umum Lokasi Penelitian

\begin{tabular}{lll}
\hline No & \multicolumn{1}{c}{ Pengamatan Lapangan } & \multicolumn{1}{c}{ Hasil } \\
\hline 1. & Kedalaman drainase & 3 Meter \\
2. & Lebar drainase & 2,5 Meter \\
3. & Kedalaman gambut & 3 Meter \\
4. & Kematangan gambut & $25-30 \%$ Hemik \\
5. & Warna gambut & 10 YR 2/1 Coklat Kehitaman \\
\hline
\end{tabular}

\section{Uji Independent Sampel T Test}

Uji independent sample $t$ test bertujuan untuk melihat apakah ada perbedaan yang signifikan diantara gambut terbakar dan tidak terbakar pada setiap parameter yang diamati yaitu; permeabilitas, berat volume, kadar air dan porositas.

\section{Uji Independent Sampel T Test Permebilitas}

Hasil uji statistik pada parameter permeabilitas diperoleh grup statistik sebagai berikut, dengan jumlah sampel pada gambut terbakar adalah 6 sampel dan tidak terbakar 2 sampel dengan rata-rata permeabilitas gambut terbakar 21,203 cm/jam lebih kecil dari gambut tidak terbakar $32,840 \mathrm{~cm} / \mathrm{jam}$. Data grup statistik parameter permeabilitas jelasnya dapat dilihat pada Tabel 7.

Tabel 7. Grup Statistik Parameter Permeabilitas

\begin{tabular}{clcccc} 
Parameter & \multicolumn{1}{c}{$\begin{array}{c}\text { Terbakar dan } \\
\text { Tidak } \\
\text { Terbakar }\end{array}$} & N & Mean & Std. Deviasi & Std. Error \\
\hline Permeabelitas & Terbakar & 6 & 21,203 & 3,853 & 1,573 \\
& Tidak & 2 & 32,840 & 0,226 & 0,160 \\
& Terbakar & & & &
\end{tabular}

Sumber: Data Hasil Uji Independent Sampel T-Test (2019)

Nilai signifikan untuk menguji homogenitas diketahui 0,086 $>0,05$ sehingga dalam uji $\mathrm{t}$ dipilih jalur atas dengan $\mathrm{t}$ hitung $(-4,050)<\mathrm{t}$ tabel $(1,943)$ dan dapat disimpulkan tidak ada perbedaan yang signifikan pada parameter permebilitas diantara gambut terbakar dan tidak terbakar. Data uji independent sampel $t$ test pada parameter permeabilitas dapat dilihat pada Tabel 8.

Tabel 8. UJi Independent Sampel T Test Parameter Permeabilitas

\begin{tabular}{ccccccccc}
\hline & & & & \multicolumn{2}{c}{$\begin{array}{c}\text { Sig. (2- } \\
\text { tailed) }\end{array}$} & $\begin{array}{c}\text { Mean } \\
\text { Difference }\end{array}$ & $\begin{array}{c}\text { Std. } \\
\text { Error }\end{array}$ & \multicolumn{2}{c}{$\begin{array}{c}\text { 95\% Confidence Interval of the } \\
\text { Difference }\end{array}$} \\
\hline Sig. & $\mathrm{T}$ & $\mathrm{df}$ & & & Lower & Upper \\
\hline Porositas & 0,086 & $-4,050$ & 6 & 0,007 & $-11,636$ & 2,873 & $-18,667$ & $-4,605$ \\
& & $-3,359$ & 5,101 & 0,001 & $-11,636$ & 1,581 & $-15,677$ & $-7,595$ \\
\hline
\end{tabular}

Sumber: Data Hasil Uji Independent Sampel T-Test (2019)

Perubahan Beberapa Sifat Fisika Dan Kimia Gambut Akibat Lamanya Penggunaan Lahan di Rawa Tripa 


\section{Uji Independent Sampel T Test Berat Volume}

Hasil uji statistik pada parameter berat volume diperoleh grup statistik sebagai berikut, dengan jumlah sampel pada gambut terbakar adalah 6 sampel dan tidak terbakar 2 sampel dengan rata-rata berat volume gambut terbakar $0,293 \mathrm{~g} \mathrm{~cm}^{-3}$ lebih kecil dari gambut tidak terbakar $0,180 \mathrm{~g} \mathrm{~cm}^{-3}$. Data grup statistik parameter berat volume dapat dilihat pada Tabel 9 .

Tabel 9. Grup Statistik Parameter Berat Volume

\begin{tabular}{clcccc}
\hline Parameter & $\begin{array}{c}\text { Terbakar dan } \\
\text { Tidak } \\
\text { Terbakar }\end{array}$ & N & Mean & Std. Deviasi & Std. Error \\
\hline Berat Volume & $\begin{array}{l}\text { Terbakar } \\
\text { Tidak }\end{array}$ & 6 & 0,293 & 0,432 & 0,017 \\
& Terbakar & 2 & 0,180 & 0,141 & 0,010
\end{tabular}

Sumber: Data Hasil Uji Independent Sampel T-Test (2019)

Nilai signifikan untuk menguji homogenitas diketahui 0,224>0,05 sehingga dalam uji $\mathrm{t}$ dipilih jalur atas dengan $\mathrm{t}$ hitung $(3,482)>\mathrm{t}$ tabel $(1,943)$ dan dapat disimpulkan ada perbedaan yang signifikan pada parameter berat volume diantara gambut terbakar dan tidak terbakar. Data uji independent sampel $t$ test parameter berat volume dapat dilihat pada Tabel 10.

Tabel 10. Data UJi Independent Sampel T Test Parameter Berat Volume

\begin{tabular}{|c|c|c|c|c|c|c|c|c|}
\hline & Sig. & $\mathrm{T}$ & $\mathrm{df}$ & $\begin{array}{l}\text { Sig. (2- } \\
\text { tailed) }\end{array}$ & $\begin{array}{c}\text { Mean } \\
\text { Difference }\end{array}$ & $\begin{array}{l}\text { Std. } \\
\text { Error }\end{array}$ & \multicolumn{2}{|c|}{$\begin{array}{l}\text { 95\% Confidence Interval of the } \\
\text { Difference }\end{array}$} \\
\hline & & & & & & & Lower & Upper \\
\hline \multirow[t]{2}{*}{$\begin{array}{l}\text { Berat } \\
\text { Volume }\end{array}$} & 0,224 & 3,482 & 6 & 0,013 & 0,113 & 0,325 & 0,033 & 0,192 \\
\hline & & 5,590 & 5,757 & 0,002 & 0,113 & 0,202 & 0,063 & 0,163 \\
\hline
\end{tabular}

Sumber: Data Hasil Uji Independent Sampel T-Test (2019)

\section{Uji Independent Sampel T Test Kadar Air}

Hasil uji statistik pada parameter permeabilitas diperoleh grup statistik sebagai berikut, dengan jumlah sampel pada gambut terbakar adalah 6 sampel dan tidak terbakar 2 sampel dengan rata-rata kadar air gambut terbakar 0,201\% lebih kecil dari gambut tidak terbakar 0,271\%. Data grup statistik parameter kadar air dapat dilihat pada Tabel 11.

Tabel 11. Grup Statistik Parameter Kadar Air

\begin{tabular}{clcccc}
\hline Parameter & $\begin{array}{l}\text { Terbakar dan } \\
\text { Tidak } \\
\text { Terbakar }\end{array}$ & N & Mean & Std. Deviasi & Std. Error \\
\hline Kadar Air & Terbakar & 6 & 0,201 & 34,630 & 14,137 \\
& Tidak & 2 & 0,271 & 10,790 & 7,630 \\
\hline
\end{tabular}

Sumber: Data Hasil Uji Independent Sampel T-Test (2019)

Perubahan Beberapa Sifat Fisika Dan Kimia Gambut Akibat Lamanya Penggunaan Lahan di Rawa Tripa Kabupaten Nagan Raya 
Nilai signifikan untuk menguji homogenitas pada parameter kadar air diketahui 0,198 > 0,05 sehingga dalam uji independent sampel $t$ test dipilih jalur atas dengan $t$ hitung $(-4,109)<$ $\mathrm{t}$ tabel (1,943), (dalam pengujian $\mathrm{t}$ tabel dilihat pada tabel $\mathrm{t}$ dengan nilai df 8 dan nilai $\alpha 0,05$ ) dan dapat disimpulkan tidak ada perbedaan yang signifikan pada parameter kadar air diantara gambut terbakar dan tidak terbakar. Data uji independent sampel $t$ test pada parameter kadar air, untuk lebih jelasnya dapat dilihat pada Tabel 12 .

Tabel 12. Grup Statistik UJi Independent Sampel T Test Parameter Kadar Air

\begin{tabular}{|c|c|c|c|c|c|c|c|c|}
\hline & Sig. & $\mathrm{T}$ & df & $\begin{array}{l}\text { Sig. (2- } \\
\text { tailed) }\end{array}$ & $\begin{array}{c}\text { Mean } \\
\text { Difference }\end{array}$ & $\begin{array}{l}\text { Std. } \\
\text { Error }\end{array}$ & \multicolumn{2}{|c|}{$\begin{array}{l}\text { 95\% Confidence Interval of the } \\
\text { Difference }\end{array}$} \\
\hline & & & & & & & Lower & Upper \\
\hline \multirow[t]{2}{*}{ Kadar Air } & 0,198 & $-4,109$ & 6 & 0,006 & $-107,078$ & 26,061 & $-170,848$ & $-43,308$ \\
\hline & & $-6,665$ & 5,854 & 0,001 & $-107,078$ & 16,065 & $-146,628$ & $-67,528$ \\
\hline
\end{tabular}

Sumber: Data Hasil Uji Independent Sampel T-Test (2019)

\section{Uji Independent Sampel T Test Porositas}

Hasil uji statistik pada parameter porositas diperoleh grup statistik sebagai berikut, dengan jumlah sampel pada gambut terbakar adalah 6 sampel dan tidak terbakar 2 sampel dengan rata-rata porositas gambut terbakar 78,120\% lebih kecil dari gambut tidak terbakar 94,355\%. Data grup statistik parameter porositas dapat dilihat pada Tabel 13.

Tabel 13. Grup Statistik Parameter Porositas

\begin{tabular}{clcccc}
\hline Parameter & $\begin{array}{c}\text { Terbakar dan } \\
\text { Tidak } \\
\text { Terbakar }\end{array}$ & N & Mean & Std. Deviasi & Std. Error \\
\hline Porositas & Terbakar & 6 & 78,120 & 10,095 & 4,121 \\
& Tidak & 2 & 94,355 & 0,813 & 0,575 \\
& Terbakar & & & & \\
\hline
\end{tabular}

Sumber: Data Hasil Uji Independent Sampel T-Test (2019)

Nilai signifikan untuk menguji homogenitas pada parameter porositas diketahui $0,76>$ 0,05 sehingga dalam uji independent sampel $t$ test dipilih jalur atas dengan t hitung sebesar $2,156<\mathrm{t}$ tabel yaitu 1,943 (dalam pengujian $\mathrm{t}$ tabel dilihat pada tabel $\mathrm{t}$ dengan nilai df 8 dan nilai $\alpha$ 0,05) dan dapat disimpulkan tidak ada perbedaan yang signifikan pada parameter porositas diantara gambut terbakar dan tidak terbakar. Data uji independent sampel $t$ test pada parameter kadar air lebih jelasnya dapat dilihat pada Tabel 14.

\begin{tabular}{|c|c|c|c|c|c|c|c|c|}
\hline & Sig. & $\mathrm{T}$ & $\mathrm{df}$ & $\begin{array}{l}\text { Sig. (2- } \\
\text { tailed) }\end{array}$ & $\begin{array}{c}\text { Mean } \\
\text { Difference }\end{array}$ & $\begin{array}{l}\text { Std. } \\
\text { Error }\end{array}$ & \multicolumn{2}{|c|}{$\begin{array}{l}\text { 95\% Confidence Interval of the } \\
\text { Difference }\end{array}$} \\
\hline & & & & & & & Lower & Upper \\
\hline \multirow[t]{2}{*}{ Porositas } & 0,76 & $-2,156$ & 6 & 0,074 & $-16,235$ & 7,529 & $-34,659$ & 2,189 \\
\hline & & $-3,901$ & 5,187 & 0,011 & $-16,235$ & 4,161 & $-26,817$ & $-5,652$ \\
\hline
\end{tabular}

Sumber: Data Hasil Uji Independent Sampel T-Test (2019)

Perubahan Beberapa Sifat Fisika Dan Kimia Gambut Akibat Lamanya Penggunaan Lahan di Rawa Tripa Kabupaten Nagan Raya

(Teuku Muhammad Afrizal, Hairul Basri, M. Rusli Alibasyah)

Jurnal Ilmiah Mahasiswa Pertanian Unsyiah, Vol. 4, No. 1, Januari 2019: 472-481 


\section{SIMPULAN DAN SARAN}

Nilai sifat fisika gambut di setiap parameter pada kedalaman $20-40 \mathrm{~cm}$ lebih kecil dibandingkan pada kedalaman $40-80 \mathrm{~cm}$, dapat dilihat pada parameter berat volume gambut terbakar 2015 nilai berat volume pada kedalaman $20-40 \mathrm{~cm}\left(0,24 \mathrm{~g} \mathrm{~cm}^{-3}\right)$ lebih kecil dibandingkan pada kedalaman $40-80 \mathrm{~cm}\left(0,26 \mathrm{~g} \mathrm{~cm}^{-3}\right)$, pada parameter kadar air di gambut terbakar 2015 nilai kadar air pada kedalaman 20 - $40 \mathrm{~cm}$ 146,94\% lebih kecil dibandingkan pada kedalaman 40 - $80 \mathrm{~cm}$ yaitu $174,34 \%$, begitu pula pada parameter yang lainnya. Dari hasil uji independent sampel $t$-test diantara gambut terbakar dan tidak terbakar pada parameter berat volume terdapat perbedaan siginifikan karena nilai $\mathrm{t}$ hitung $>\mathrm{t}$ tabel yaitu : 3,482 > 1,943 sedangkan pada parameter kadar air, permeabilitas, porositas tidak ada perbedaan yang signifikan karena nilai $t$ hitung < t tabel, diharapkan adanya kepedulian dan pengetahuan yang lebih baik lagi, baik itu bagi masyarakat dan beberapa perusahaan terkait dalam mengelola gambut baik untuk keperluan pertanian maupun kelestarian gambut itu sendiri, agar tidak mengganggu keseimbangan ekosistem gambut yang mana dapat memberikan feedback kepada manusia berupa bencana seperti banjir dan global warming.

\section{DAFTAR PUSTAKA}

Agus, F. dan I. G. M. Subiksa. 2008. Lahan gambut: potensi untuk pertanian dan aspek lingkungan. Balai Penelitian Tanah dan World Agroforestry Centre (ICRAF), Bogor, Indonesia.

Prijono, A. 2016. Rawa tarung pertaruhan di rawa gambut tripa. Jakarta. KEHATI.

Sabiham, S. 2007. Pengembangan lahan secara berkelanjutan sebagai dasar dalam pengelolaan gambut di Indonesia. Makalah Utama Seminar Nasional Pertanian Lahan Rawa. Kapuas 3-4 Juli 2007.

Subiksa, I.G.M., S. Husein dan J. Purnomo. 2009. Pengembangan formula pupuk untuk lahan gambut sebagai penyedia hara dan menekan emisi gas rumah kaca (GRK). Laporan Kerja Sama antar Balai Penelitian Tanah dengan Departemen Pendidikan Nasional, 2009.

Tahrun, M., Wawan dan A. I. Amri. 2015. Perubahan sifat fisika gambut akiba kebakaran di Desa Teluk Binjai Kecamatan Teluk Meranti Kabupaten Pelalawan. Jom Faperta Vol 2 No 1 2015. Fakultas Agroteknologi. Riau.

Wahyunto, S. Ritung, Suparto dan H. Subagjo. 2004. Sebaran gambut dan kandungan karbon di Sumatera dan Kalimantan. Proyek Climate Change, Forests and Peatlands in Indonesia. Wetlands International - Indonesia Programme dan Wildlife Habitat Canada. Bogor.

Perubahan Beberapa Sifat Fisika Dan Kimia Gambut Akibat Lamanya Penggunaan Lahan di Rawa Tripa 